\title{
Comparison between the Effect of Feeding Corn Silage or Berseem as a Basal Diet on: 1- Milk Production and Economic Efficiency of Lactating Friesian Cows. Sayed-Ahmed, M. E. \\ Animal Production Research Institute, Agriculture Research Center, Ministry of Agriculture, Dokki, Giza, Egypt.
}

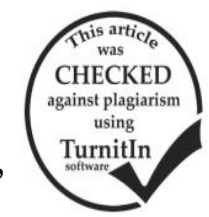

\section{ABSTRACT}

Twelve lactating Friesian cows with the average body weight of 490-560 kg were used in this study. All animals were in the second to fourth lactation season. Cows were randomly distributed into three similar groups (four for each group) to study the effect of the tested rations on milk production and its composition. All groups were individually fed according to NRC (2001) recommendations. The experimental period lasted for 140 days (20 weeks) after calving. The three experimental rations were formulated nearly as follows: (Control): $40 \%$ concentrate feed mixture (CFM) $+32 \%$ rice straw (RS) $+28 \%$ corn silage (S), (Exp.1): $40 \%$ concentrate feed mixture (CFM) $+32 \%$ rice straw (RS) $+28 \%$ berseem (B) and (Exp. 2$): 40 \%$ concentrate feed mixture (CFM) $+32 \%$ rice straw (RS) $+14 \%$ corn silage $(\mathrm{S})+14 \%$ berseem (B). The average daily milk yield was the highest $(\mathrm{p}<0.05)$ with group fed exp.1 from W1 to W12 compared with the control ration, while there were no significant effect between exp.1 and exp.2 or exp.2 and control ration. The average milk yield were $12.69,16.05$ and $15.17 \mathrm{Kg} /$ day with feeding on control, exp.1 and exp.2 respectively. The milk composition of protein\% was higher $(\mathrm{p}<0.05)$ with feeding on exp.2 $(2.51 \%)$ than feeding on exp.1 $(2.29 \%)$, but there was no significant effect between exp.1 and control ration (2.37\%) or feeding on exp.2 and control ration. The net energy (NEL Mcal $/ \mathrm{kg}$ milk) values were significantly $(\mathrm{p}<0.05)$ higher with feeding on control or exp.2 $(0.64$ and $0.63 \mathrm{Mcal} / \mathrm{kg}$ milk respectively) than feeding on exp.1 ( $0.60 \mathrm{Mcal} / \mathrm{kg}$ milk). The protein yield and lactose yield $(\mathrm{kg} /$ day) were increased $(\mathrm{p}<0.05)$ with feeding on exp. 1 and exp.2 rations than feeding on control ration. The highest values of feed conversion (DMI kg/kg FCM) and net energy of the milk (Mcal $/ \mathrm{kg}$ milk) were with feeding on rations containing corn silage (control) or corn silage with berseem (exp.2) than ration which containing berseem only (exp.1). The highest values $(p<0.05)$ of feed cost were estimated with exp.1 (40.01 LE) and exp.2 (38.07 LE) than feeding on the control diet (36.09 LE), but there was no significant affect between the control and exp.2 or exp.1 and exp.2. With the same trend the profit (LE) values were higher $(p<0.05)$ with feeding an exp.1 (21.63 LE) or feeding with exp.2 (18.69 LE) than feeding with the control $(15.35 \mathrm{LE})$. Corn silage is an important source of digestible effective fibre and can be an economical source of $\mathrm{CP}$ in diets for lactating cows, but increased passage rate with feeding berseem which is more digestible forage NDF might increase efficiency of milk production and composition. So feeding on exp.1 or exp.2 resulted in improving milk production, feed conversion and economic efficiency.

Keywords: Lactating Friesian cows, Corn silage, berseem, milk production, milk composition.

\section{INTRODUCTION}

Forage utilization is still inconsistent. The cow's requirements receive most her dietary nutrients from the forage. Dry matter intake (DMI) reduce as crude protein in forage fell below about 7\% (Adams, 1997).

Maximizing feed intake is important in increasing energy and glucose supply from acetate and propionate. Also, increasing amino acids supply which is required for synthesis of milk protein. As a result of large amounts of nutrients obtained from diet, cow's dependence on body stores will be reduced giving more chance to produce milk without great losses from the body condition. After calving, metabolic diseases occurrence will be reduced by increasing feed intake (Emery, 1993). Starch is a more suitable energy source than glucose for maximum capture of ammonia-N for microbial synthesis (Grishwold et al 1996). The growth of mixed ruminal bacteria is a linear function of the amounts of carbohydrate fermented in the rumen. Microbial digestion within the rumen has always caused difficulties with prediction of nutrient supply to ruminant animals. Starch and fibre digestion are influenced by high corn silage diets which results in affecting both energy metabolism and DMI in lactating dairy cows (Allen et al, 2009).

The nature and the proportion of the concentrate as well as the quality of the roughage control the extent of the concentrate effect on digestion of fibre. Diet formulation of ruminants depends on the net energy of lactation (Belyea et al 1999). Information about efficiency of energy consumption by ruminants is important for ideal production of milk from lactating dairy cows (Jhonson et al 2003) and essentially the nutritive value of rely on cell content : cell wall ratio and on the capability of microorganisms in rumen to break down the cell wall of the plant. Plant cell walls made up of polysaccharides which cross linked with proteins and phenolic compounds as lignin which present in cell wall commonly. Mostly, the fiber fractions originate from cell walls of the plant and considered as a necessary part of diet in the ruminants. Cellulose, hemicelluloses and pectic polysaccharides considered as the main polysaccharides of cell wall of the plant. The nitrogen input and high quality fodder can be provided by forage legumes. Comparing grasses with grassland legumes, it is found that the latter has better feeding value, higher intake and animal production (Frame et al 1998).

The main target of this study was to estimate the feeding effect of corn silage or berseem as a basal diet on milk production and economic efficiency of lactating Friesian cows.

\section{MATERIALS AND METHODS}

The present study was conducted at El-Karada Animal Production Research Station, Animal Production Research Institute, Agricultural Research Centre, Ministry of Agricultural. Twelve lactating Friesian cows from the herd of the station were ranging from $490-560 \mathrm{~kg}$ were used in this study. All animals were in the second to fourth lactation season. Cows were randomly distributed into three similar groups (four for each group) to study the effect of the tested rations on milk production and its composition. All 
group were individually fed according to NRC (2001) recommendations, based on their live body weight and milk yield (requirement for maintenance was $1 \%$ of LBW concentrate $+1 \%$ of LBW roughage and requirement for lactation was $1 / 2 \mathrm{Kgconcentrat}$ per $1 \mathrm{Kg}$ milk yield ). The experimental period lasted for 140 days (20 weeks). The three experimental rations were formulated nearly as follows: (Control): $40 \%$ concentrate feed mixture $(\mathrm{CFM})+32 \%$ rice straw (RS) $+28 \%$ corn silage (S), (Exp.1): $40 \%$ concentrate feed mixture $(\mathrm{CFM})+32 \%$ rice straw $(\mathrm{RS})+28 \%$ berseem (B) and (Exp.2): $40 \%$ concentrate feed mixture (CFM) $+32 \%$ rice straw $(\mathrm{RS})+14 \%$ corn silage $(\mathrm{S})+14 \%$ berseem (B).

Management of feeding the concentrate feed mixture was offered firstly at morning, while corn silage or berseem and rice straw was offered after consumption of the concentrate feed mixture. Drinking fresh and clean water was available at all times.

Milk yield was recorded individually twice daily for each cow and about $0.5 \%$ of the total milk yield was taken for analysis from each animal individually during the experimental periods (proportionate sample from morning and evening) of both control and tow tested rations in the end every four weeks. The analysis included fat, total protein, lactose, total solids (TS) and solids non-fat (SNF) in milk. The chemical analysis of milk samples was carried out according to Ling (1963). Samples of concentrate mixture, corn silage, berseem and rice straw were taken at the beginning, middle and at the end of each trial. At the end of the collection period composite samples were dried in a forced air oven at $65^{\circ} \mathrm{C}$ for 48 hours, then ground and kept for chemical analysis. Dried samples were composted for each cow and representative samples were taken, ground and kept for chemical analysis.

Chemical analysis of samples of concentrate mixture, corn silage, berseem and rice straw were carried out to determine dry matter (DM), crude protein (CP), crude fiber (CF), ether extract (EE), ash and fiber fractions (NDF,ADF ADL, Hemi. and Cell.) according to the methods of AOAC (1990) and the experimental rations were formulated as shown in Table (1).

Data were statistically analyzed by variance test method according to Snedecor and Cochran (1982) while the differences among means were tested using Duncan's Multiple Test (Duncan, 1955).

Table 1. The chemical composition of the ingredients and experimental rations.

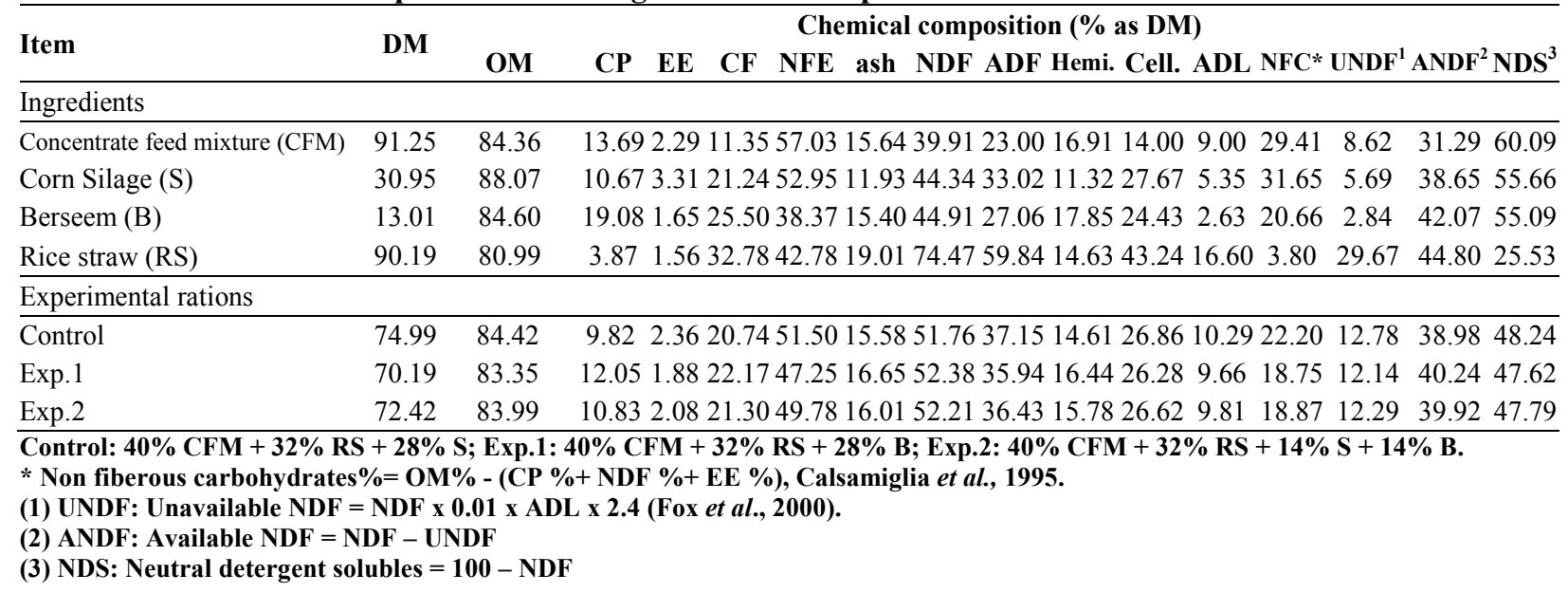

\section{RESULTS AND DISCUSSION}

Average monthly milk yield and its chemical composition are presented in Tables $(2$ and 3 respectively) and as shown in Figures (1 and 2). The average daily milk yield was the highest $(\mathrm{p}<0.05)$ with group fed exp.1 from W1 to W12 compared with the control ration, while there were no significant effect between exp. 1 and exp. 2 or exp. 2 and control ration.

Table 2. Effect of feeding the experimental rations on average monthly milk yield of the lactating Friesian cows

\begin{tabular}{lccc}
\hline Items & Control & Exp.1 & Exp.2 \\
\hline W1-4 & $15.43^{\mathrm{b}}$ & $19.09^{\mathrm{a}}$ & $18.22^{\mathrm{ab}}$ \\
$\mathrm{W} 5-8$ & $12.43^{\mathrm{b}}$ & $16.60^{\mathrm{a}}$ & $15.32^{\mathrm{ab}}$ \\
$\mathrm{W} 9-12$ & $12.56^{\mathrm{b}}$ & $15.39^{\mathrm{a}}$ & $14.75^{\mathrm{ab}}$ \\
$\mathrm{W} 13-16$ & 11.33 & 14.88 & 13.83 \\
W17-20 & 11.73 & 14.28 & 13.72 \\
Average & $12.69^{\mathrm{b}}$ & $16.05^{\mathrm{a}}$ & $15.17^{\mathrm{ab}}$ \\
\hline a, b and ab: Means within the same raw with different
\end{tabular}
superscripts are significantly different $(p<0.05)$

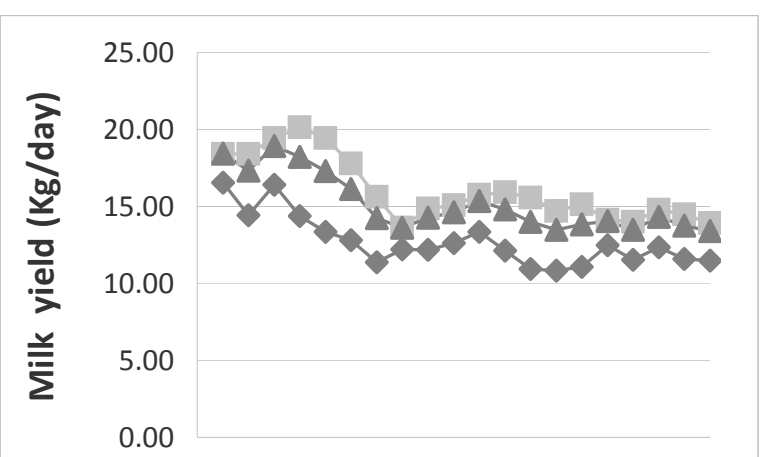

01234567891011121314151617181920

Weeks

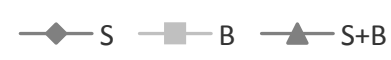

Fig. 1. Effect of feeding the experimental rations on average weekly milk yield of the lactating Friesian cows 
The average milk yield was the highest $(\mathrm{p}<$ $0.05)$ with feeding on ration exp.1 (16.05 kg/day) compared with the control ration $(12.69 \mathrm{~kg} /$ day $)$. Milk production in the first month of lactation influences the production in later months. Practically, it is difficult to obtain high energy intake by using diets rich in fibre and low in non fibrous carbohydrates. This can be achieved if highly digestible fibre is used in diet. The fibre used should not put physical constraints on intake. So, the forage is chopped or grinded to reduce these physical constraints (Cannas, 2002).

Table 3. Effect of feeding lactating caws on experimental rations on some chemical composition of milk.

\begin{tabular}{|c|c|c|c|}
\hline Items & Control & Exp.1 & Exp.2 \\
\hline $\mathrm{T} . \mathrm{S} \%$ & 11.04 & 10.09 & 10.62 \\
\hline Fat $\%$ & 3.56 & 3.26 & 3.38 \\
\hline Lactose $\%$ & 4.57 & 4.39 & 4.53 \\
\hline Protein $\%$ & $2.37^{\mathrm{ab}}$ & $2.29^{b}$ & $2.51^{\mathrm{a}}$ \\
\hline $\mathrm{SNF} \%$ & 7.48 & 6.83 & 7.15 \\
\hline $\mathrm{NEL}(\mathrm{Mcal} / \mathrm{Kg})^{*}$ & $0.64^{\mathrm{a}}$ & $0.60^{b}$ & $0.66^{\mathrm{a}}$ \\
\hline Fat corrected milk FCM ${ }^{* *}$ & 12.86 & 15.41 & 14.15 \\
\hline Fat yield $\mathrm{Kg}$ /day & 0.454 & 0.522 & 0.479 \\
\hline Protein yield $\mathrm{Kg}$ /day & $0.301^{\mathrm{b}}$ & $0.367^{\mathrm{a}}$ & $0.339^{\mathrm{a}}$ \\
\hline Lactose yield $\mathrm{Kg}$ /day & $0.577^{\mathrm{b}}$ & $0.704^{\mathrm{a}}$ & $0.647^{\mathrm{a}}$ \\
\hline
\end{tabular}

a, b and ab: Means within the same raw with different superscripts are significantly different $(\mathbf{p}<0.05)$

* NEL $($ Mcal $/ \mathrm{kg})=(0.0929 \times$ Fat \%) $+(0.0547 \times$ Protein \%) + (0.0395 x Lactose \%) (NRC, 2001)

**FCM : Average of dairy production of calculated $3.5 \%$ fat corrected milk (Kg/day)

FCM $(\mathrm{Kg} /$ day $)=0.432 \mathrm{X}$ milk $(\mathrm{Kg})+16.23 \mathrm{X}$ fat $(\mathrm{Kg})$ (Britt et al 2003)

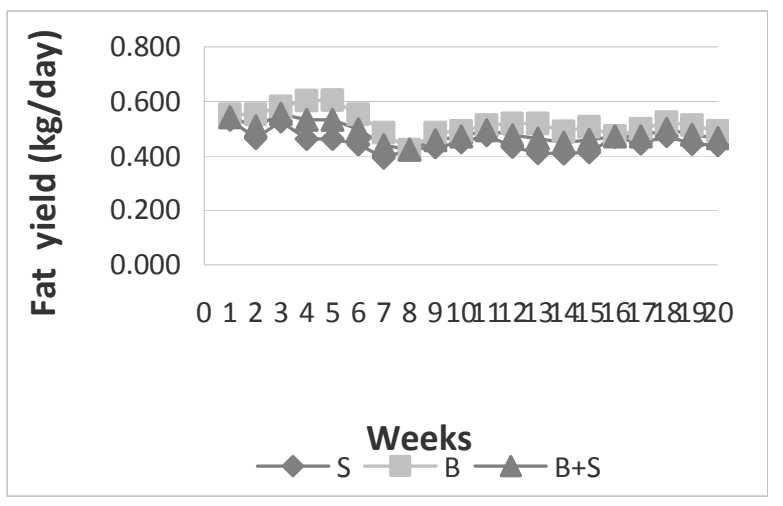

Fig. 2. Effect of feeding the experimental rations on average weekly fat milk yield of the lactating Friesian cows

Regarding the milk composition (Table 3), protein $\%$ was higher $(\mathrm{p}<0.05)$ with feeding on exp. 2 $(2.51 \%)$ or control ration $(2.37 \%)$ than feeding on exp. 1 $(2.29 \%)$, but there was no significant effect between exp.1 and control ration. The net energy (NEL Mcal $/ \mathrm{kg}$ milk) values were significantly $(p<0.05)$ higher with feeding on control or exp.2 (0.64 and $0.63 \mathrm{Mcal} / \mathrm{kg}$ milk respectively) than feeding on exp.1 ( $0.60 \mathrm{Mcal} / \mathrm{kg}$ milk).

The protein and lactose yield (kg/day) were increased $(\mathrm{p}<0.05)$ with feeding on exp.1 and exp.2 rations than feeding on control ration. Since the fibre content of the ration of dairy cows is inversely proportional to its energy content (NRC, 1989). Replacing neutral detergent fibre with non fibrous carbohydrates results in higher milk production, higher energy content of the diet and lower milk fat content. The effect of dietary protein on milk fat is not obvious. Dietary protein is manipulated to increase milk production and DM intake. Ammonia-N may be provided to fibre digesting bacteria by ruminal protein degradation. Buffering the rumen environment can be achieved because of releasing ammonia by protein degradation (Santos et al 1998).

Ration crude protein (CP) levels in rations should be reduced for two primary reasons. One of these reasons is to increase profitability by improving the efficiency of converting feed $\mathrm{N}$ intake to milk $\mathrm{N}$ output while at least maintaining milk production. The capability of the dairy cow to store nitrogen is limited compared with energy. Evaluation of nitrogen use efficiency in the dairy cow can be done by using (MNE) index. The MNE values observed in commercial dairy herds usually ranges between 20 and $35 \%$. This means that 65 to $80 \%$ of the consumed $\mathrm{N}$ is excreted in the manure (Olmos Colmenero and Broderick, 2006).

The net energy of lactation (NEL) requirement of the cow generally defines the maximum amount of NDF to include in a ration. The maximum NDF in the ration is also the minimum amount of NFC needed for good ruminal fermentation and to avoid negative affects on dry matter intake related to high NDF levels (Akins et al 2012).

Table (4) data indicated that the highest values of feed conversion (DMI $\mathrm{kg} / \mathrm{kg}$ FCM) were with feeding on rations containing corn silage (control) or corn silage with berseem (exp.2) than ration which containing berseem only (exp.1).

Table 4. Effect of feeding experimental rations on feed conversion of lactating Friesian cows.

\begin{tabular}{|c|c|c|c|}
\hline Items & Control & Exp.1 & Exp.2 \\
\hline$\overline{\mathrm{DMI}}(\mathrm{Kg} / \mathrm{h} /$ day $)$ & 16.59 & 16.33 & 16.46 \\
\hline Fat corrected milk FCM & 12.86 & 15.41 & 14.15 \\
\hline DMI Kg/ Kg FCM & $1.30^{\mathrm{a}}$ & $1.06^{\mathrm{b}}$ & $1.18^{\mathrm{a}}$ \\
\hline
\end{tabular}
are significantly different $(p<0.05)$

Some researches reported that feeding corn silage (CS) ad libitum increased DMI and performance of cattle (Keady et al 2007). Corn grain is incorporated within the whole plant so there is energy from grain along with fibre from the rest of the plant. Mazzenga et al (2009) reviewed the diets included along with (wheat straw and CS), dried beet pulp, soybean meal, corn meal, wheat bran and mineral premix, with the stepped substitution of wheat straw with $\mathrm{CS}$, the forage to concentrate ratio were as follows: 40:60, 50:50, 60:40 and 70:30 respectively.

The highest digestibility data was that of $50 \%$ inclusion of CS (for DM, OM, CP, NDF and ADF). They stated that CS had a positive effect on DM digestibility through the increase of NDF and OM digestion while increasing CS inclusion. 


\section{J. Animal and Poultry Prod.., Mansoura Univ., Vol. 7 (12), December, 2016}

NRC (National Research Council), (2001). Nutrient requirements of dairy cattle, $7^{\text {th }}$ rev. ed. National Academy Sci., Washington, DC.

Olmos Colmenero, J.J. and G.A. Broderick (2006). Effect of dietary crude protein concentration on milk production and nitrogen utilization in lactating dairy cows. J. Dairy Sci. 89:1704.
Santos, F.A.P., J.E.P. Santos, J.T. Huber and C.B. Theurer (1998). Effects of rumen undegredable protein on dairy cow performance : A 12 year literature review. J. Dairy Sci. 81:3182.

Snedecor, G.W. and W.G. Cochran (1982). Statistical Methods. 7th Ed. Iowa State Univ. Press. Ames. Iowa.

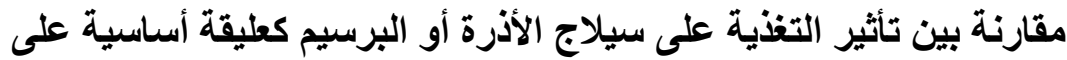

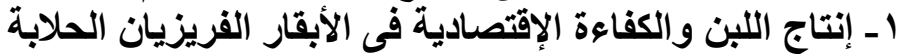

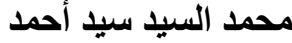 معهة بحوثٌ الإنتاج الحيو اني ـ مركز البحوث الزراعية ـ وزارة الزراعة ـ الدقي ـ الجيزة ـ مصر.}

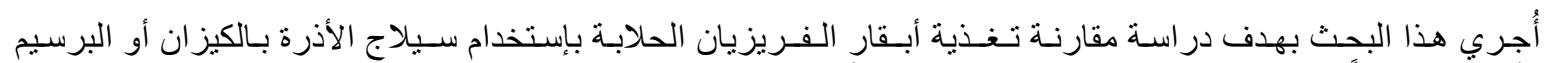

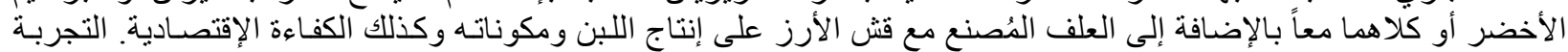

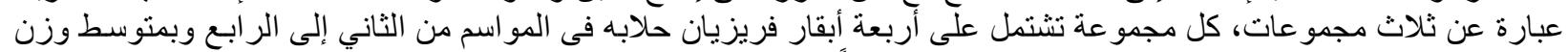

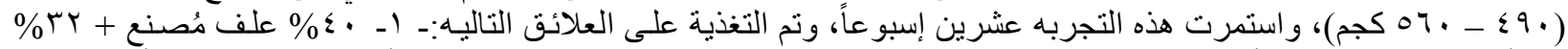

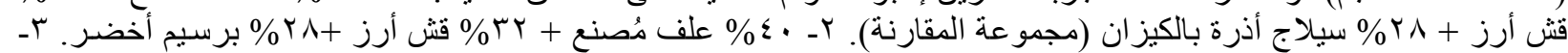

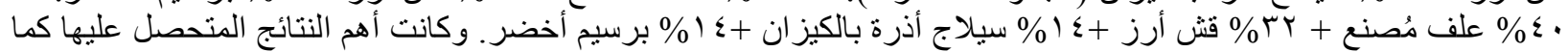

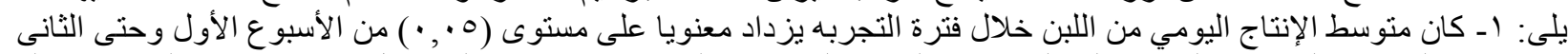

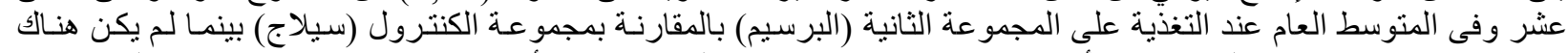

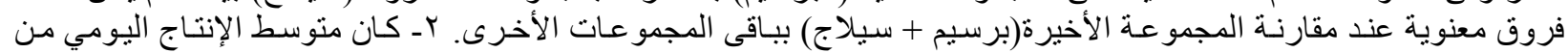

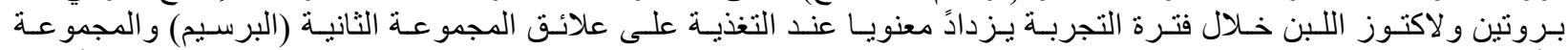

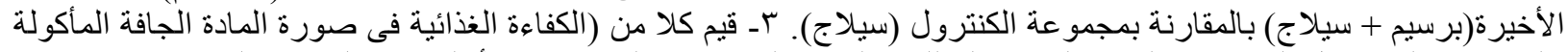

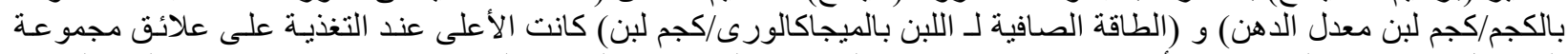

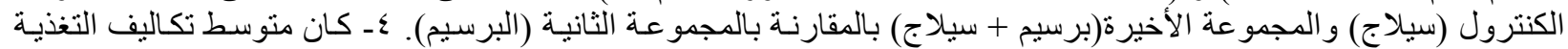

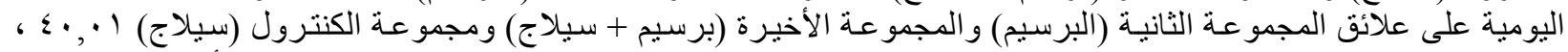

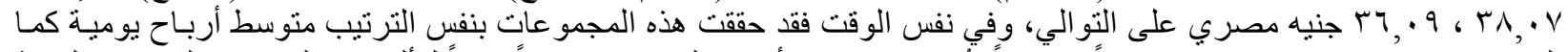

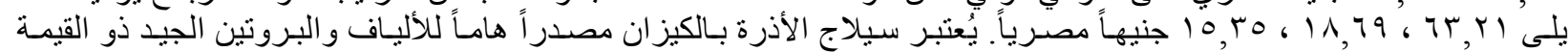

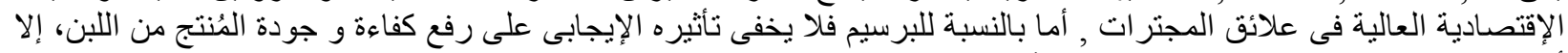

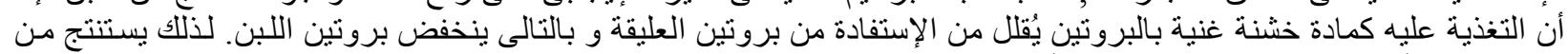

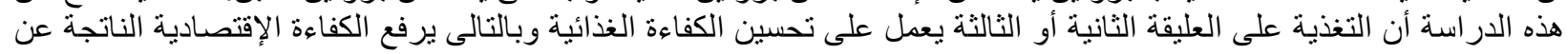
إستخدام هذه الخلطات العلفية. 